\title{
ANALYSIS OF THREE ANTECEDENT DIMENSIONS OF SERVICE TOWARDS CONSUMER'S TRUST AND THEIR IMPACT ON POST-PURCHASE BEHAVIOR
}

\author{
Retno Dewanti ${ }^{1}$; Wendy Teoh $^{2}$; Yulia Wati ${ }^{3}$; Rahayu ${ }^{4}$ \\ ${ }^{1,4}$ Jurusan Manajemen, Fakultas Ekonomi dan Komunikasi, Binus University; \\ Jl. KH. Syahdan No. 9, Palmerah, Jakarta Barat 11480. \\ ${ }^{2}$ Universiti Teknologi MARA Malaysia; ${ }^{3}$ Chosun University Korea \\ wantibukit@yahoo.com,myteoh@mmu.edu.my, yuliawati@gmail.com
}

\begin{abstract}
In the last few years retail industry in Indonesia has been grown rapidly by three main factors, namely economic, demographic and socio-cultural. If a retail business can gain success in Malaysia, it may not gain the same success in Indonesia. A research is conducted using associative analysis by correlation test with path analysis technique and Pearson Product Moment correlation. The results of this research show that three antecedents of service variables - interaction quality, the quality of physical environment, and outcome quality are related to each other and simultaneously influence consumer's trust. Regarding to the partial analysis, it is found that the quality of physical environment and consumer's trust has significant effects on post-purchase behavior. Path analysis shows that three antecedents of service indirectly contribute to consumer post-purchase behavior through consumer's trust. However, the outcome quality provides the largest contribution on it.
\end{abstract}

Keywords: interaction, environment, outcome, trust, post purchase, behavior

\begin{abstract}
ABSTRAK
Dalam beberapa tahun terakhir bisnis ritel di Indonesia telah berkembang pesat yang dipengaruhi tiga faktor utama, yaitu ekonomi, demografi dan sosial-budaya. Jika suatu bisnis ritel dapat meraih sukses di Malaysia, mungkin tidak mendapatkan keberhasilan yang sama di Indonesia. Sebuah penelitian dilakukan dengan menggunakan analisis asosiatif berdasarkan uji korelasi dengan teknik analisis jalur dan korelasi Pearson Product Moment. Hasil penelitian ini menunjukkan bahwa tiga variabel anteseden layanan - kualitas interaksi, kualitas lingkungan, dan kualitas hasil - terkait satu sama lain dan secara simultan mempengaruhi kepercayaan konsumen. Berdasarkan analisis parsial, ditemukan bahwa kualitas lingkungan fisik dan kepercayaan konsumen memiliki efek yang signifikan terhadap perilaku pasca pembelian. Analisis jalur menunjukkan bahwa tiga anteseden pelayanan secara tidak langsung berkontribusi kepada perilaku pasca pembelian konsumen melalui kepercayaan konsumen. Namun, kualitas hasil memberikan kontribusi terbesar.
\end{abstract}

Kata kunci: interaksi, lingkungan, hasil, kepercayaan, pasca pembelian, perilaku 


\section{INTRODUCTION}

Indonesia's retail growth in 2006 is 14.3 percent (PT ACNielsen Indonesia, n.d.). From 2003 to 2006 the shopping centers specializing on consumer goods had begun to emerge from minimarket to hypermarket (Tabel 1).

Tabel 1 Amount of Shopping Cebters in Indonesia from 2003 - 2006

\begin{tabular}{ccccc}
\hline Retail type & 2003 & 2004 & 2005 & 2006 \\
\hline Minimarket & 4.038 unit & 5.604 unit & 6.465 unit & 7.476 unit \\
Supermarket & 896 unit & 956 unit & 1.141 unit & 1.277 unit \\
Hypermarket & 67 unit & 90 unit & 106 unit & 138 unit \\
\cline { 2 - 5 } Source: Aprindo/Data Consult/ICN & & & &
\end{tabular}

PT. Hero Supermarket, Tbk. as one of the largest retailer in Indonesia operates more than 300 outlets under several brand names such as HERO, Giant, Guardian, Starmart Mini Mart, Shop In and Mitra. Up to 2006, 37 HERO Pasar Swalayan outlets have been spread in Jakarta (the annual Report of HERO 2006). Lately HERO changed its name with Giant, carried out together with the change of customer's trust and purchase behavior. The prickly competition that does not go along with the quality service resulted in the decline in customer number. Thus, they cannot maintain their loyal customers and face difficulties in looking for new customers.

The first endeavor carried out by HERO is changing its name with Giant in purpose to gain consumer's trust and increase the purchase as Giant Malaysia does. Giant and HERO Pasar Swalayan are under management of Dairy Farm International Giant Retail Sdn Bhd. Since 1998, Dairy Farm International that is based in the USA, England, Hongkong, Malaysia invested its share in PT. Hero Supermarket Tbk.

According to Christina Whidya (2006), the development of the retail industry is bound with the influence of three main factors - economics, demography and social the culture. The supportive economic growth factor of retail industry is per capita income. The second factor is demography - an increase in inhabitants number. The third is social culture factor, such as lifestyle change and the current shopping custom which is in one-stop shopping places that is safe, comfortable, reachable and also able to be used for recreation.

It is important for the retail industry at this time to increase the service quality as an effort to develop the customer's trust in gaining success in modern retail sector. The trust formed will trigger the consumers to purchase more. This research is carried out to examine the change in the retail management strategy.

\section{Literature Study}

\section{Service Quality}

Aaker (2003, p72) defines service as something that could not be felt, produced and consumed simultaneously; only the results of the service that can be observed. In other words, Ma'ruf (2006, p.226) describes service as an activity, the benefits and satisfaction from something that is offered in the sale. Employers should be able to customize the type of services offered by other elements in the Retail Mix. Some indicators for service quality are: (1) quality of interaction - attitude, behavior, and experiences of employees; (2) quality of the physical environment - ambience or atmosphere, design and social factor; (3) quality of outcome - waiting period, tangibility and valence (Jasfar, 2005). 


\section{Consumer's Trust}

According to Wood et al (2008, p.27), theory of trust is based on three views: (1) Trust is an individual's learned expectancy about others based on outcomes from personal interactions with others; (2) Trust develops out of assessments based on repeated observations (history) of a trustee's behaviors; (3) Trust building is a calculative process analyzing potential costs versus potential benefits.

Consumer's trust allows organization to take risks that are fundamental to new business innovations and productivity. In the knowledge based society of the $21^{\text {st }}$ century, the increasingly intangible and tacit nature of knowledge assets and resources requires a greater level of an understanding between consumers and organizations, taking into account the social welfare of both consumers and organizations (Chong Ju Choi et al, 2007, p18).

There are six factors in developing the consumer's trust: (1) competence - the capacity owned by the company; (2) credibility - the company is deserved to be trusted; (3) reliability - the company owns test-passed products; (4) integrity - the company should be honest and have social responsibility; (5) benevolence - the company supports assistance for their consumer; (6) informative - the company provides information needed by their consumers.

\section{Consumer's Behavior}

Consumer behavior is a actions happened to the consumer when he or she decided to buy, what to buy, where, when and how (Ma'ruf 2006, p.50).

Farida Jasfar (2005) states that indicators of purchase decision are: (1) Loyalty, which means the willingness to became the customer in the future even when the customers experience inconvenience; (2) behavior intensity which means that: (a) consumers are likely to recommend the supermarket service to the others; (b) consumers do not need to move to other supermarkets after experiencing inconveniences or problems in the current supermarket; (c) consumers are offered the better price that they do not need to move to other supermarkets; (3) Although the prices increase consumers will not move to other supermarkets.

\section{METHOD}

The research uses samples from 100 Giant's customers with $\alpha=0,05$ and that will make $\mathrm{Z} \alpha=$ 1,96 and the accepted estimation is $10 \%$. The correlation test is carried out to know if any significant relations between the dependent variable and the independent's variables. Technically the analysis of the Pearson Product Moment correlation includes the statistical technique parametric using the interval data and the ratio with certain condition (Kuncoro and Riduwan 2007, pp61-62).

This research uses the model of two path equities as below:

$$
\begin{gathered}
Y=\rho Y X 1_{1}+\rho Y X 1_{2}+\rho Y X 1_{3}+\varepsilon_{1}(\text { as sub-structure } 1) \\
Z=\rho Z X 1_{1}+\rho Z X 1_{2}+\rho Z X 1_{3}+\rho Z Y+\varepsilon_{2}(\text { as sub-structure } 2)
\end{gathered}
$$

Below is the Framework of thinking to analyze the dependent variables and independent variables (Figure 1). 


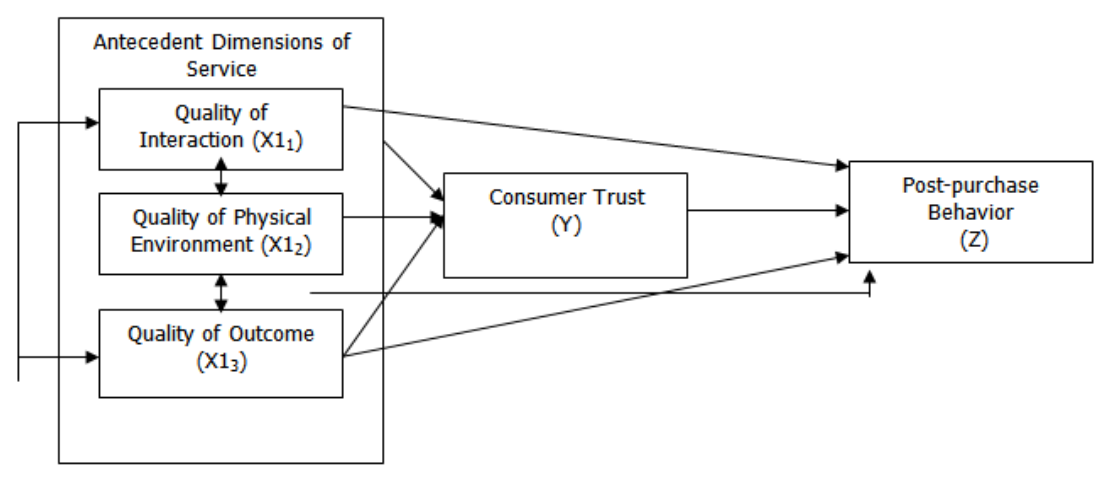

Figure 1 Framework of Thinking

Legends:

$\mathrm{X} 1_{1}=$ Independent variable

$\mathrm{X}_{2}=$ Independent variable

$\mathrm{X}_{3}=$ Independent variable

$\mathrm{Y}=$ Dependent variable

$\mathrm{Z}=$ Dependent variable

Based on the literature study and the analysis of framework of thinking, then several hypotheses can be formulated as follows:

Hypothesis 1 : There are some significant relations between the quality of the interaction variable, the quality of the physical environment variables and the quality of outcome variable.

Hypothesis 2 : Quality factors of the interaction, the quality of the physical environment and the quality of outcome contribute significantly towards the consumer's trust.

Hypothesis 3 : The quality of the interaction, the quality of the physical environment, the quality of outcome contribute significantly the consumer's trust is influential towards postpurchase behavior in Giant Supermarket.

\section{RESULTS AND DISCUSSIONS}

In general the consumer assessment against the variable of three service antecedents is 3.39 that including hesitant. This means that on the whole the assessment of the consumer concerning the quality of three dimensions of service antecedents owned by Giant Hypermarket is hesitant. So the consumers still have doubts on the service quality of Giant Hypermarket. Therefore, from the three dimensions of the service antecedents, the highest score is for the adequate numbers of ATM facilities provided, whereas for the lowest score is for the waiting period of the service.

In general the consumer assessment against the variable of three dimensions of the service antecedent is 3.54 that including agreeing. This means that on the whole the assessment of the consumer concerning the consumer's trust is to agree. So the consumer are agreed to the trust formed in Giant Hypermarket. The highest score of the consumer's trust variable is that any information given by Giant Hypermarket is reliable, whereas for the lowest score is that the employee can be always trusted.

The consumer assessment towards the post-purchase behavior is 3.00 including hesitant. It means that thoroughly the consumer still distrust the post-purchase behavior in Giant Supermarket. That the consumer will recommend to the other person gains the highest score, whereas that the employee always could be trusted gains the lowest score. 
The quality of the interaction namely attitude, behavior and employee's experience is connected in a quite strong manner, significantly in accordance with the physical environment including the ambience (the atmosphere), the design and the social factor. The quality of the interaction namely the attitude, the behavior and the employee's experience is connected in a quite strong manner, significantly in accordance with the outcome as follows - waiting period, tangibility and valence.

The physical environment including the condition ambience (the atmosphere), the design and the social factor are connected in a quite strong manner, significantly in accordance with the quality outcome as follows - waiting period, tangibility and valence.

The simultaneous influence is shown with the significance figure of $0.000<0.05$ and Fcount $>$ table $(47.732>2.70)$ then $\mathrm{H} 1$ is accepted and $\mathrm{H} 0$ is refused. In other words, the quality factors of the interaction, the quality of the physical environment and the quality of output contribute significantly towards the consumer's trust. Partially the quality of the interaction contributes significantly towards the consumer's trust by 0.349 or $34.9 \%$. The quality of physical environment contributes significantly towards the consumer's trust by 0.192 or $19,2 \%$. The quality of outtcome contributes significanltly towards the counsumer trust by 0,388 or $38,8 \%$. The quality of the interaction, the quality of the physical environment, the quality of outcome and the consumer's trust in a manner combine the contribution towards the post-purchase behavior by $42.1 \%$. Partially the quality of the physical environment contributes significantly towards the post-purchase behavior by 0.212 or $21,2 \%$. The consumer's trust contributes significantly towards the post-purchase behavior by 0.312 or $31.2 \%$.

To give more comprehension about the figures mentioned, see Figure 2 below.

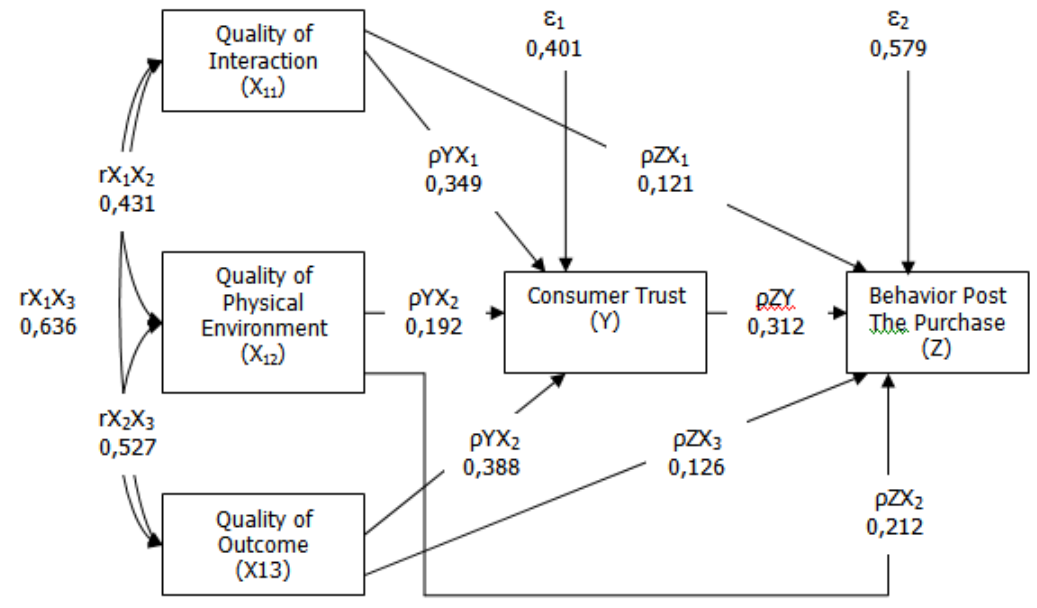

Figure 2 Path chart

The structural equation for this model is:

$$
\begin{gathered}
\mathrm{Y}=0,349 \mathrm{X} 1_{1}+0,192 \mathrm{X} 1_{2}+0,388 \mathrm{X} 1_{3}+\varepsilon_{1} \\
\mathrm{Z}=0,121 \mathrm{X} 1_{1}+0,212 \mathrm{X} 1_{2}+0,126 \mathrm{X} 1_{3}+0,312 \mathrm{Y}+\varepsilon_{2}
\end{gathered}
$$

Based on the calculation above, several results are gained as follows: (1) Contribution of the quality of interaction towards the post-purchase behavior is 0,121 or $12,1 \%$; (2) Contribution of the quality of physical environment towards the post-purchase behavior is 0,212 or $21,2 \%$; (3) Contribution of the quality of outcome towards the $r$ post-purchase behavior is 0,126 or $12,6 \%$; (4) Contribution of the consumer's trust towards the post-purchase behavior is 0,312 or $31,2 \%$; 
Contribution of the quality of interaction, quality of physical environment, quality of outcome and consumer's trust in a manner the combination towards the post-purchase behavior is 0,421 or $42,1 \%$; (6) The other variable contribution outside the model towards post-purchase behavior is 0,579 or $57,9 \%$; (7) Contribution of the quality of interaction towards the post-purchase behavior through the consumer's trust is 0,458 or $45,8 \%$; (8) Contribution of the quality of physical environment towards the post-purchase behavior through the consumer's trust is 0,252 or $25,2 \%$; (9) Effect of quality of outcome variable towards the post-purchase behavior through the consumer's trust is 0,509 or $50,9 \%$; (10) Contribution of the quality of interaction towards the consumer's trust is 0,349 or $34,9 \%$; (11) Contribution of the quality of physical environment towards the consumer's trust is 0,192 or $19,2 \%$; (12) Contribution of the outcome quality towards the consumer trust is 0,388 or $38,8 \%$; (13) Contribution of the interaction of the quality variable, the quality of the physical environment and the quality of outcome in a manner the combination towards the consumer's trust is 0.599 or $59,9 \%$; (14) other variable contribution outside the model towards the consumer's trust is 0.401 or $40,1 \%$.

\section{CONCLUSION}

From the explanation above, the variable that is most influenced to consumer's trust is quality of outcome which is $38.8 \%$. The variable of three antecedent dimensions of the service that influences the post-purchase behavior most is the quality of the physical environment which is $21.2 \%$. The quality of the interaction and the quality of output does not influential significantly; the two variables only influence the post-purchase behavior through consumer's trust. Therefore, Giant Hypermarket is better to increase the quality of the service to gain the consumer's trust so that the post-purchase behavior can be increased which may increase the consumer's loyalty and the intensity of the buying.

\section{REFERENCES}

Aaker, K. (2003). Marketing Research. New Jersey: Prentice Hall.

Chong Ju Choi; Eldomiaty, Tarek Ibrahim; Sae Won Kim. (2007). Consumer Trust, Social Marketing \& Ethics of Welfare Exchange. Journal of Business Ethics, 74 (1), 17 - 23. Diakses dari http://www.mendeley.com/research/consumer-trust-social-marketingethics-welfare-exchange/.

Ma’ruf, Hendri. (2006). Pemasaran Ritel. Jakarta: PT Gramedia Pustaka Utama.

Riduwan, Kuncoro. (2007). Cara Menggunakan Dan Memaknai Analisis Jalur (Path Analiysis). Bandung: Alfabeta.

Whidya, Christina. (2006). Manajemen Ritel Strategi dan Implementasi Ritel Modern. Jakarta: Salemba Empat. 